\title{
Changes in the concentrations of testosterone and androstenedione in the plasma and testis of the guinea-pig from birth to death
}

\author{
N. Rigaudière, G. Pelardy, A. Robert and P. Delost \\ Laboratoire de Physiologie Animale, and ERA CNRS d'Endocrinologie du Développement, \\ Université de Clermont, Ensemble Scientifique des Cézeaux, B.P.45, 63170 Aubière, France
}

\begin{abstract}
Summary. Testosterone and androstenedione concentrations in the plasma and testis of male guinea-pigs were estimated by gas chromatography at intervals ( 36 stages) from birth to death. Four main periods of androgenic activity were recognized. The neonatal period, from birth to Day 16 , is characterized by a precocious but transient peak in plasma testosterone concentration at Days 2 and 3. The pubertal period from Days 16 to 90 can be subdivided into a prepubertal period starting on Day 16 and marked by a sudden linear increase in plasma and testicular testosterone concentration together with an increase in testicular and seminal vesicle weight, and a postpubertal period, from Day 50 (the time of hormonal puberty) to Day 90 , characterized by high and stable androgen levels while testicular and genital tract development continues. Adulthood spans the period between Months 3-6 and Month 24; plasma and testicular concentrations of testosterone and androstenedione are stable but lower than those observed during puberty. The period of senescence occurs between Months 24 and 28 and is marked by a fall in testosterone secretion and involution of the seminiferous tubules and accessory sex glands.
\end{abstract}

\section{Introduction}

Recent studies on male mammals have shown that the hormonal secretions of the testis change during the life of an animal, particularly during specific periods of reproductive activity. For example, relatively high androgen levels have been recorded at birth in the plasma and testis of man (Forest, Cathiard \& Bertrand, 1973a, b), monkey (Resko, 1970b), rat (Döhler \& Wuttke, 1975) and lamb (Attal, 1970). During puberty the amount of androgens increases in different compartments in man (Frasier, Gafford \& Horton, 1969; August, Grumbach \& Kaplan, 1972; Knorr, Bidlingmaier, Butenandt, Fendel \& Ehrt-Wehle, 1974), rat (Knorr, Vanha-Perttula \& Lipsett, 1970; Döhler \& Wuttke, 1975; Gupta, Zarzycki \& Rager, 1975b), mouse (McKinney \& Desjardins, 1973) and lamb (Courot, 1971). Androgen concentrations during adulthood and senescence have been particularly well studied in man (Vermeulen, Rubens \& Verdonck, 1972; Nieschlag, Kley, Wiegelmann, Solbach \& Krüskemper, 1973; Pirke \& Doerr, 1973; Stearns et al., 1974): there is a notable decrease in old age from the stable levels in the adult. However, no investigation has so far been made on the secretion of androgens between birth and death of animals of the same species. Only such a study can provide precise information on the critical stages of transition between the main periods of androgenic activity. We have therefore studied the changes in plasma and testicular testosterone and androstenedione concentrations from birth to death in the guinea-pig, a species for which there is little information (Rivarola, Snipes \& Migeon, 1968; Resko, 1970a).

\section{Materials and Methods}

\section{Animals}

The study was carried out on about 1000 male guinea-pigs of the Dunkin-Hartley strain which were born and bred in the laboratory. Newborn animals of both sex remained with the mother until 
weaning on Day 20. Young males were then kept together until 3 months of age. Adults were regularly used for breeding from 3 to 24 months of age. The animals were killed by decapitation. Blood was collected from the neck, centrifuged and deep frozen at $-35^{\circ} \mathrm{C}$, as were the testes. Some gonads and seminal vesicles were used for histological study. Newborn animals were killed at $0,6,12,18$ and $24 \mathrm{hr}$ after birth. The others were killed between 09.00 and 11.00 hours on Days 2, 3, 4, 5, 6, 7, $8,9,10,12,14,16,18$ and 20 of age during the neonatal period; on Days $30,40,45,50,55,60,70$, 80 and 90 of age during puberty; and at Months 6,9,18,20,22, 24, 28, 31 and 35 for adulthood and senescence. Death for Dunkin-Hartley male guinea-pigs was estimated by a statistical study to occur on average at 25 months of age.

\section{Assays}

Concentrations of testosterone and androstenedione were estimated by gas-liquid chromatography with electron capture detection (tritiated source) according to the micromethod of Attal (1970): unconjugated hormones were extracted with ether; testosterone and androstenedione were separated by thin-layer chromatography; androstenedione was reduced to testosterone with sodium borohydride; testosterone was converted to testosterone-17 $\beta$ heptafluorate and then measured with an $\mathrm{F}$ and $\mathrm{M}$ Biochemical 402 chromatograph. The method gave recovery values of known amounts of $\left[1,2-{ }^{3} \mathrm{H}\right]$ testosterone and $\left[1,2-{ }^{3} \mathrm{H}\right]$ androstenedione (sp.act. $40-50 \mathrm{Ci} / \mathrm{mmol}$ : New England Nuclear Corporation) of $40 \%$ for testosterone and $20 \%$ for androstenedione; sensitivity was $1 \mathrm{ng}$ for testosterone and $5 \mathrm{ng}$ for androstenedione. Precision was given by a coefficient of variation $<10 \%$ for quantities higher than $5 \mathrm{ng}$ for the two hormones. Androgens were measured in the testes of each animal and 10-20 estimations were made at each stage. Plasma androgens were estimated on pooled samples of plasma (2-8 animals in each pool) in the $0 \mathrm{hr}$ to 20-day-old animals and on 10-20 individual samples in the others. Concentrations are expressed as $\mathrm{ng} / 10 \mathrm{ml}$ plasma and as $\mathrm{ng} / 2$ testes. Means are given with the standard error (S.E.M.); probability and significance were calculated by Student's $t$ test.

\section{Results}

Changes in body, testicular and seminal vesicle weight

These are shown in Text-fig. 1 ; the values were more or less parallel throughout life. Testicular weight increased linearly $(y=49 \cdot 13 x-705 \cdot 19 ; r=0.99)$ between Days 16 and 90 of life. Thereafter the weight increased slightly until Month 6, remained stable until Month 28, and then decreased by $22 \%(0.02<P<0.05)$. Between Day 18 and Month 6 , the linear increase of seminal vesicle weight was marked $(y=24.04 x-183.48 ; r=0.96)$. The weight continued to increase from Months 6 to 18 (34\%, 0.02<P<0.05), then steadily decreased by $43 \%$ at Month $35(P<0.001)$.

\section{Histology}

In most individuals, the first spermatozoa appeared in the seminiferous tubules between Days 55 and 60. Spermatogenesis was regular until Month 22. Thereafter disruptions could be seen in the seminiferous epithelium and about $25 \%$ of tubules were beginning to involute although epididymal sperm reserves appeared normal. From Month 31 involution affected $50 \%$ of tubules (diminution in germ cells, elimination of the multinucleated cells of degeneration, deformation of the tubule) and was followed by a depletion of the spermatozoa in the epididymis. Nevertheless, at this age spermatogenic activity remained apparently normal in $50 \%$ of animals. Histological study of the seminal vesicles showed that the epithelium was well stimulated until Month 24 . At Month 28, slight involution appeared in $30 \%$ of the animals. By Month $3165 \%$ of seminal vesicles displayed a poorly stimulated or atrophied epithelium and at Month 35 the seminal vesicles of all animals were atrophied. 


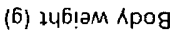

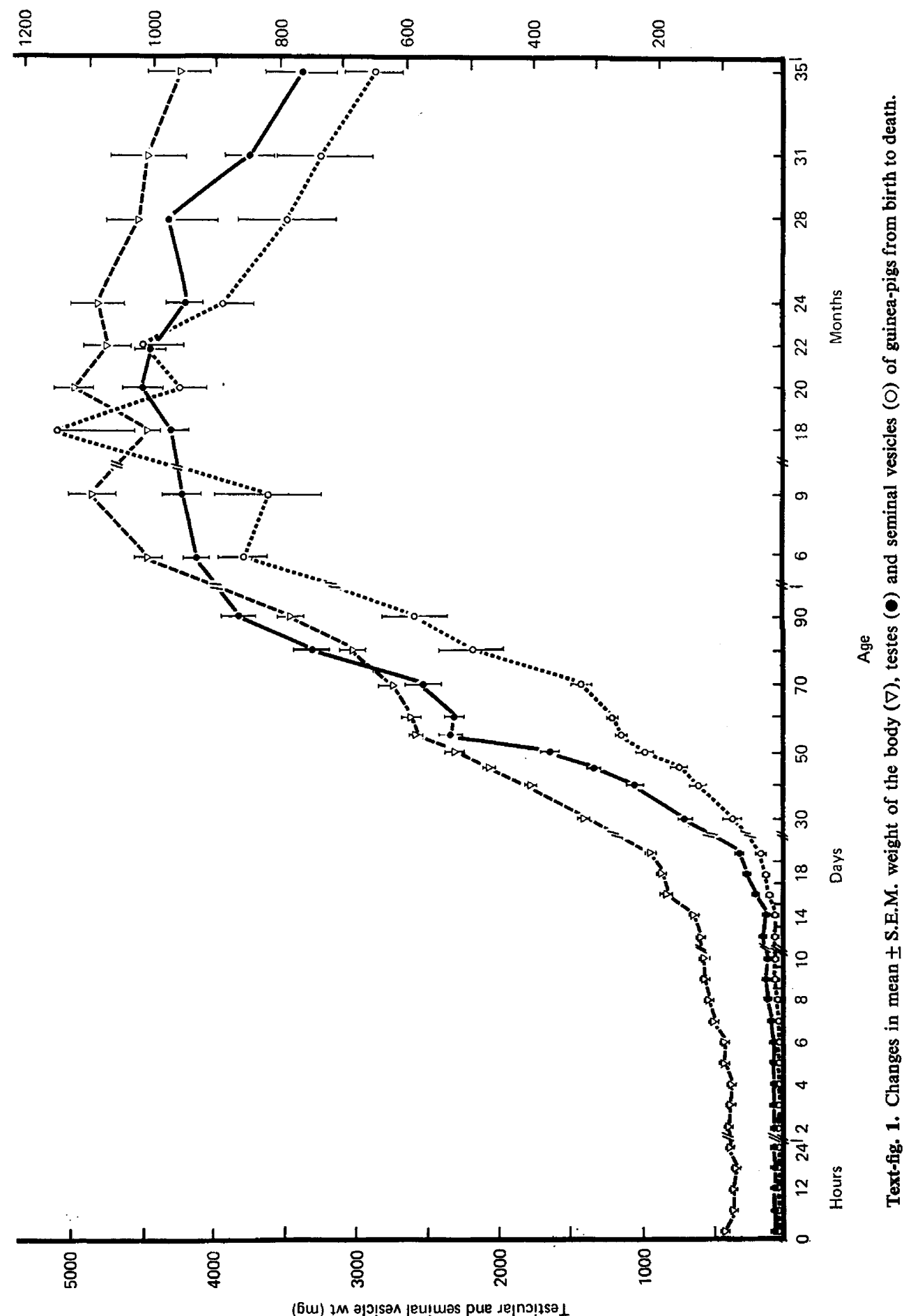

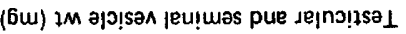




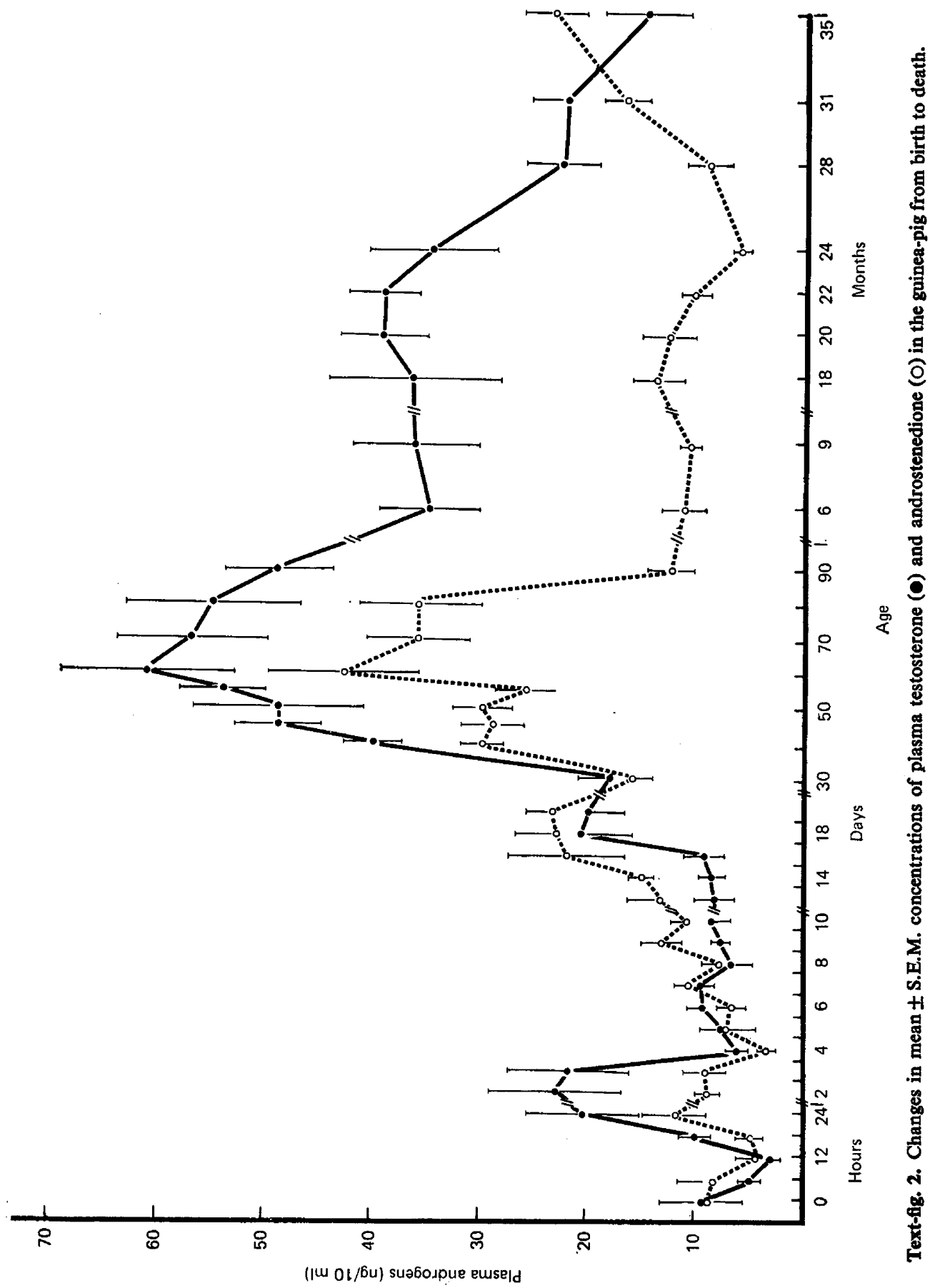




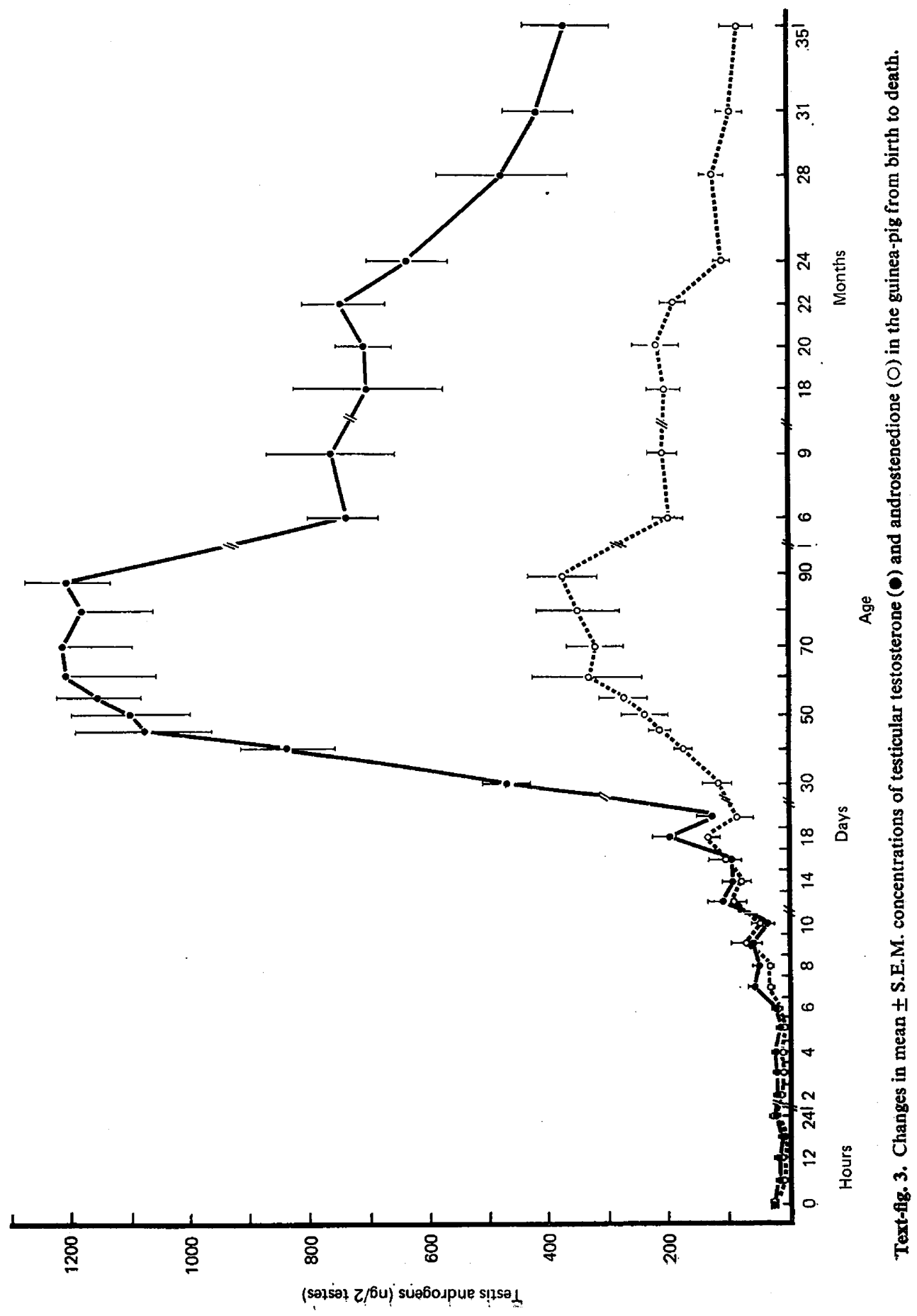




\section{Changes in plasma concentrations of testosterone and androstenedione}

These are shown in Text-fig. 2. Testosterone concentration on Day 3 was significantly higher than that at $12 \mathrm{hr}(P<0.001)$ and on Day $4(0.02<P<0.05)$. No similar increase of androstenedione was observed. From Day 4, the two androgens behaved differently: the plasma androstenedione level regularly increased until Day 60, while plasma testosterone levels remained stable between Days 4 and 16, then increased rapidly until Day 60. Maximal values were reached on Day 60 for both androgens. Plasma testosterone and androstenedione concentrations then regularly decreased to Month 6 , by $43 \%(P<0.001)$ and $72 \%(0.01<P<0.001)$ respectively. In old animals testosterone decreased by $65 \%(P<0.001)$ between Months 24 and 35, while androstenedione decreased by $53 \%(0.01<P<0.02)$ between Months 20 and 24 , then increased by $28 \%(P<0.001)$ between Months 24 and 35.

The ratio of plasma androstenedione:testosterone varied between birth and death, being $<1$ in early life (to Day 6), $>1$ from Day 7 to weaning, always $<1$ in the young and the adult, and then $>1$ in the old animals.

\section{Changes in the concentrations of testosterone and androstenedione in the testis}

These are shown in Text-fig. 3. There was little change for the first 6 days of life, but there was a significant $(P<0 \cdot 001)$ increase between Days 6 and 18. The ratio of androstenedione:testosterone remained stable and close to 1 between birth and weaning. From Days 20 to 90 , both androgens showed a second and very rapid rise of $918 \%(P<0.001)$ for testosterone and of $355 \%(P<0.001)$ for androstenedione. Between Months 3 and 6 a fall of $43 \%(P<0.001)$ occurred for testosterone and of $46 \%$ for androstenedione $(0.01<P<0.02)$. Testosterone concentrations gradually fell between Month 22 and 35; the decrease was $35 \%(0.02<P<0.05)$ at Month 28 and $50 \%(P<0.001)$ at Month 35. A $50 \%$ drop $(P<0.001)$ in androstenedione level was reached by Month 24 and the values then remained steady. The androstenedione : testosterone ratio remained $<0.4$ between Day 30 and Month 35.

\section{Discussion}

This study of plasma and testicular concentrations of testosterone and androstenedione in the guinea-pig from birth to death permits definition of four main periods during the life of the species with regard to androgen secretion. (1) The neonatal period occurs from birth to Day 16; plasma and testicular androgens are relatively low but there is a transient peak in plasma testosterone on Days 2 and 3. (2) The pubertal period occurs from Day 16 to 90 . It is characterized by a quick rise in plasma and testicular testosterone, starting on Day 16. Hormonal puberty can be considered as being reached on Day 50 and corresponds with the appearance of the first spermatozoa. The rapid increase in the seminal vesicle weight bears witness to the response of the accessory sex glands to androgens; there is, however, a reduction in the androstenedione:testosterone ratio in the testis as early as Day 18, which is due to a faster increase in testosterone production. The postpubertal period lasts from Day 50 to Day 90; during this stage plasma and testis testosterone concentrations remain stable and very high; the testis and genital tract continue to develop. (3) The period of adulthood begins between Months 3 and 6 and lasts until Month 24. The stable androgen concentrations in the plasma and testis between Months 6 and 24 can be considered as the basic values of the adult and are lower than those observed at puberty. (4) The period of senescence is that occurring when male guinea-pigs live beyond Month 24. At 28 months of age the testicular and plasma testosterone levels are very low and the drop is concomitant with a decrease in the testicular and seminal vesicle weight, a degeneration of the seminiferous epithelium and an involution of the seminal vesicle epithelium.

These four periods, based on the androgen concentrations in the plasma and testis, need to be more precisely determined by study of the metabolic clearance and testosterone rates and by corre- 
lation with the different stages of spermatogenesis, as Courot (1971) has done for the lamb. In a preliminary study on the peripheral metabolism of testosterone in the guinea-pig we have shown that the changes of testosterone production rate are parallel with those of plasma testosterone concentrations (Jarrige, Lac, Robert \& Rigaudière, 1975).

The existence of a peak in plasma testosterone during Days 1-3 in the guinea-pig was shown by Pelardy, Rigaudière \& Delost (1972) and correlates with high values of plasma LH (Donovan et al., 1975). A similar peak has been found in man between Days 30 and 60 (Forest, Cathiard, Bourgeois \& Genoud, 1974) and is associated with high LH levels (Faiman, Reyes \& Winter, 1974). However, as no parallel increase of testicular testosterone was observed in the guinea-pig, the early effect of gonadotrophins will have to be confirmed. It is possible that the adrenal gland is involved since an androstenedione peak has been observed in this gland in guinea-pigs at $12 \mathrm{hr}$ of age (Pelardy \& Delost, 1975). Although Donovan et al. (1975) did not observe a rise in plasma LH between Days 15 and 45 in the guinea-pig, it seems likely that there is gonadotrophic stimulation at this period, because of the increase in the concentrations of testicular testosterone between Days 16 and 50. A rise in plasma LH concentrations has been reported at the time of puberty in man (Wieland, Chen, Zorn \& Hallberg, 1971; August et al., 1972) and rat (Swerdloff, Walsh, Jacobs \& Odell, 1971; Miyachi, Nieschlag \& Lipsett, 1973, Döhler \& Wuttke, 1975). Since the hormonal activity of the guinea-pig testis starts well before spermiogenesis and since the testis contains large amounts of testosterone and androstenedione at puberty, even before reaching its full development, androgens or their reduced metabolites may perhaps be involved in the initiation of spermatogenesis in this species. This is not so in the lamb, in which growth of the testis directly depends upon gonadotrophic stimulation (Courot, 1971).

Higher plasma testosterone concentrations in pubertal than in adult guinea-pigs are also found in the mouse and rat, but not in ram, monkey, pig and man in which the highest values are only reached in the adult (Table 1). Our finding of a relatively low concentration of plasma testosterone in adult guinea-pigs confirms those of Rivarola et al. (1968) and Resko (1970a). These cor:centrations, like those of the dog (Tremblay et al., 1972) and rat (Table 1), may be low compared with those in rabbit (Mahoudeau, Corvol \& Bricaire, 1973), bull (Katongole, 1971), ram, monkey and man (Table 1) and may be related to the presence of testosterone-binding globulin (Corvol \& Bardin, 1973). This protein has been identified in rabbit, ram, bull, monkey and man, but not in guinea-pig, rat and dog. Therefore, testosterone, which is not protected from hepatic catabolism by a specific binding protein, would be metabolized quickly and this would explain its low concentration in plasma. The high testosterone metabolic clearance rate in the adult guinea-pig (Jarrige et al., 1975) would support this hypothesis. However, before reaching definite conclusions about the relationship between the concentrations of testosterone and age it is necessary to check the influence of the adult's sexual behaviour on its own testosterone concentrations. Indeed, our experimental adults were breeders, whereas the pubescent guinea-pigs were virgin. Preliminary study showed that in virgin adults plasma testosterone concentrations are as high as during puberty.

The drop in plasma testosterone concentration observed in the ageing guinea-pig is similar to that observed in man (Table 1) and the endocrine secretion of the testis seems to be affected before spermatogenesis. Testicular involution may be due to a failure of gonadotrophic stimulation or to a drop in the receptivity of the seminiferous tubule and Leydig tissue to gonadotrophins. The rise in plasma androstenedione established in the male guinea-pig at the end of life might be due to a change in the rate of conversion of androstenedione to testosterone in the testis or in the liver, linked perhaps with a reduction of the $17 \beta$-hydroxysteroid dehydrogenase activity or to an increased androstenedione secretion by the adrenals. Although in some species, eg. the rat (Shapiro \& Leathem, 1970), the adrenal weight does not change during senescence, in the guinea-pig the adrenals continue to increase in weight between Months 9 and 35 and plasma cortisol is very high in the old animals (unpublished observations), suggesting hyperactivity of the adrenal in the last month of life.

We should like to thank Miss A. Voldoire for technical assistance. This work was partly supported by a grant of D, G, R. S. T. contract No, 75.7.0007. 
N. Rigaudière et al.

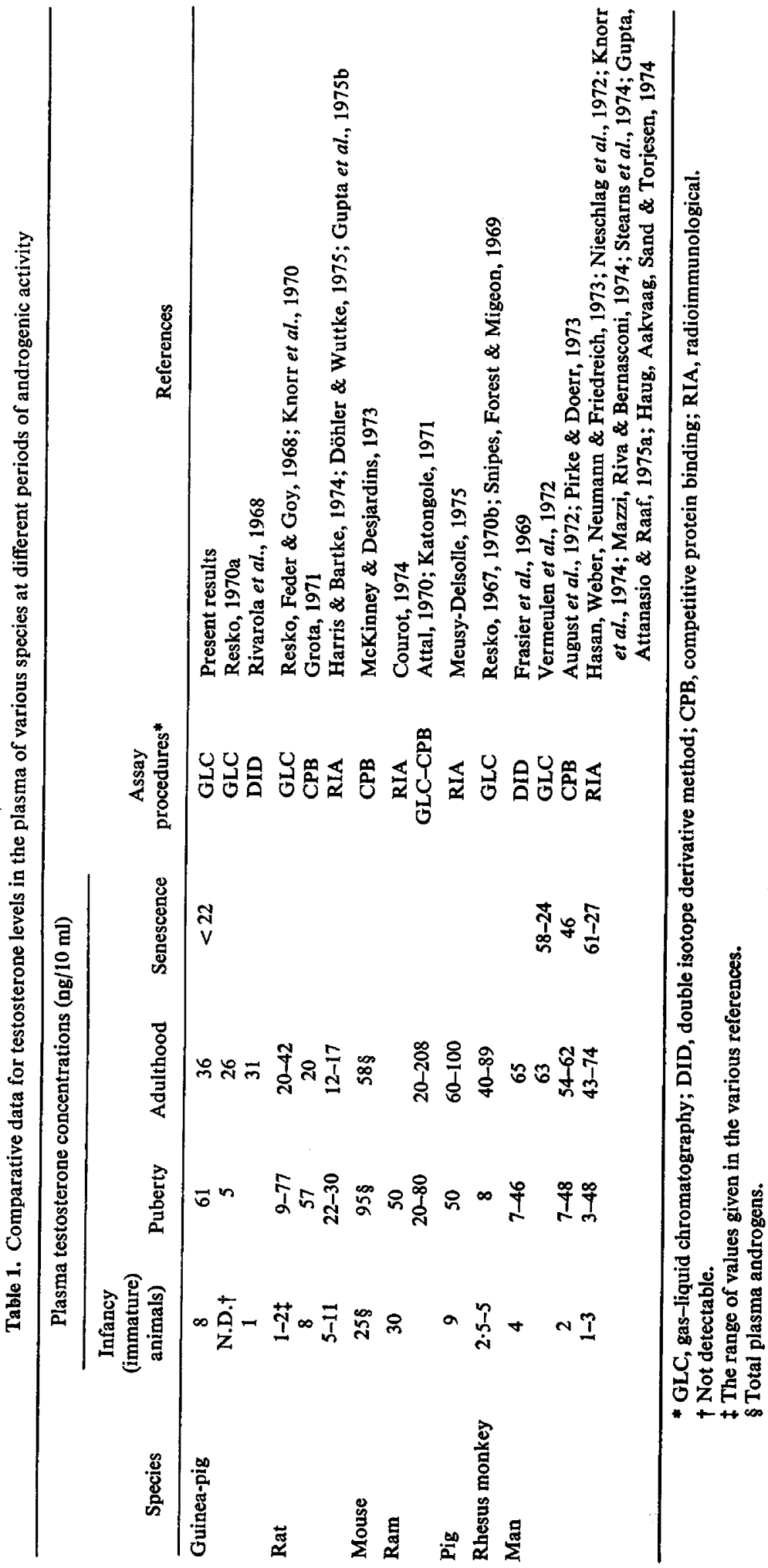




\section{References}

Atral, J. (1970) Mesure des oestrogènes et des androgènes testiculaires et plasmatiques dans l'espèce ovine par des microméthodes de chromatographie en phase gazeuse: infuence de l'âge, de la saison et du cycle diurne. Thèse Doctorat ès Sciences, Paris, pp. 1-143.

August, G.P., Grumbach, M.M. \& Kaplan, S.L. (1972) Hormonal changes in puberty. III. Correlation of plasma testosterone, $\mathrm{LH}, \mathrm{FSH}$, testicular size and bone age with male pubertal development. $J$. clin. Endocr. Metab. 34, 319-326.

Corvol, P. \& Bardin, C.W. (1973) Species distribution of testosterone-binding globulin. Biol. Reprod. 8, 277-282.

Courot, M. (1971) Etablissement de la spermatogenèse chez l'agneau (Ovis aries). Etude expérimentale de son contrôle gonadotrope: importance des cellules de la lignée sertolienne. Thèse Doctorat ès Sciences, Paris VI, pp. 1-200.

Courot, M. (1974) Blood plasma LH, testosterone and prolactin patterns in the male lamb. In Sexual Endocrinology of the Perinatal Period, Colloque INSERM 32, 157-160.

DöHLER, K.D. \& WuTTKE, W. (1975) Changes with age in levels of serum gonadotropins, prolactin and gonadal steroids in prepubertal male and female rats. Endocrinology 97, 898-907.

Donovan, B.T., Ter HaAR, M.B., Lockhart, A.N., MacKinnon, P.C.B., Mattock, J.M. \& Peddie, M.J. (1975) Changes in the concentration of luteinizing hormone in plasma during development in the guinea-pig. $J$. Endocr. 64, 511-520.

FAiman, C., Reyes, F.I. \& WinTer, J.S.D. (1974) Serum gonadotropin patterns during the perinatal period in man and in chimpanzee. In Sexual Endocrinology of the Perinatal Period, Colloque INSERM 32, 281-297.

Forest, M.G., Cathiard, A.M. \& Bertrand, J.A. (1973a) Total and unbound testosterone levels in the newborn and in normal and hypogonadal children: use of a sensitive radioimmunoassay for testosterone. J. clin. Endocr. Metab. 36, 1132-1142.

Forest, M.G., Cathiard, A.M. \& Bertrand, J.A. (1973b) Evidence of testicular activity in early infancy. J. clin. Endocr. Metab. 37, 148-151.

Forest, G., Cathiard, A.M., Bourgeois, J. \& Genoud, J. (1974) Androgènes plasmatiques chez le nourrisson normal et prématuré. Relation avec la maturation de l'axe hypothalamo-hypophyso-gonadique. In Sexual Endocrinology of the Perinatal Period, Colloque INSERM 32, 315-335.

Frasier, S.D., GAFFord, F. \& Horton, R. (1969) Plasma androgens in childhood and adolescence. $J$. clin. Endocr. Metab. 29, 1404-1408.

Grota, L.J. (1971) Effects of age and experience on plasma testosterone. Neuroendocrinology 8, 136-143.

Gupta, D., Attanasio, A. \& RaAf, S. (1975a) Plasma estrogen and androgen concentrations in children during adolescence. $J$. clin. Endocr. Metab. 40, 636-643.

GuPTA, D., ZARZYCKI, J. \& RAGER, K. (1975b) Plasma testosterone and dihydrotestosterone in male rats during sexual maturation and following orchidectomy and experimental bilateral cryptorchidism. Steroids 25, 33-42.

Harris, M.E. \& Bartke, A. (1974) Concentration of testosterone in testis fluid of the rat. Endocrinology 95, 701-706.

Hasan, S.H., Weber, B., NeumanN, F. \& Friedreich, E. (1973) Plasma testosterone levels in childhood and puberty, measured by radioimmunoassay. Acta endocr., Copenh., Suppl. 173, 168.

Haug, E., Aakvaag, A., Sand, T. \& Torjesen, P.A. (1974) The gonadotrophin response to synthetic gonadotrophin-releasing hormone in males in relation to age, dose and basal serum levels of testosterone, oestradiol-17 $\beta$ and gonadotrophins. Acta endocr., Copenh. 77, 625-635.

JARRige, J.F., LAC, G., Robert, A. \& Rigaudiere, N. (1975) Taux de clearance métabolique de la testostérone chez le Cobaye. J. Physiol., Paris 71, 290A291 A.

Katongole, C.B. (1971) A competitive protein-binding assay for testosterone in the plasma of the bull and the ram. J. Endocr. 51, 303-312.

Knorr, D., Bidlingmaier, F., Butenandt, O., Fendel, H. \& EhrT-WeHLe, R. (1974) Plasma testosterone in male puberty. I. Physiology of plasma testosterone. Acta endocr., Copenh. 75, 181-194.

Knorr, D.W., Vanha-PertTula, T. \& Lipsetr, M.B. (1970) Structure and function of rat testis through pubescence. Endocrinology 86, 1298-1304.

Mahoudeau, J.A., Corvol, P. \& Bricaire, H. (1973) Rabbit testosterone-binding globulin. II. Effect on androgen metabolism in vivo. Endocrinology 92, 1120-1125.

Mazzi, C., Riva, L.P. \& Bernasconi, D. (1974) Gonadotrophins and plasma testosterone in senescence. In The Endocrine Function of the Human Testis, Vol. II, pp. 51-66. Eds V.H.T. James, M. Serio \& L. Martini. Academic Press, New York and London.

McKinney, T.D. \& Desjardins, C. (1973) Postnatal development of the testis, fighting behavior and fertility in house mice. Biol. Reprod. 9, 279-294.

Meusy-Delsolle, N. (1975) Variations quantitatives de la testosterone plasmatique chez le Porc mâle, de la naissance à l'âge adulte. C. r. hebd. Séanc. Acad. Sci., Paris 281, 1875-1878.

Miyachi, Y., Nieschlag, E. \& LipSetT, M.B. (1973) The secretion of gonadotropins and testosterone by the neonatal male rat. Endocrinology 92, 1-5.

NieschlaG, E., Kley, H.K., WiegelmanN, W., Solbach, H.G. \& KRÜSKEMPER, H.L. (1973) Lebensalter und endokrine funktion der testes des erwachsenen Mannes. Dtsch. med. Wschr. 98, 1281-1284.

Pelardy, G. \& Delost, P. (1975) Les androgènes surrénaliens au cours du développement néonatal chez le Cobaye. J. Physiol., Paris 71, 144A-145A.

Pelardy, G., Rigaudiere, N. \& Delost, P. (1972) Evolution néonatale des androgènes plasmatiques chez le Cobaye. J. Physiol., Paris 65, 281A.

PIRKE, K.M. \& DOERR, P. (1973) Age related changes and interrelationships between plasma testosterone 
oestradiol and testosterone-binding globulin in normal adult males. Acta endocr., Copenh. 74. 792-800.

ReSKo, J.A. (1967) Plasma androgen levels of the rhesus monkey: effects of age and season. Endocrinology 81, 1203-1211.

Resko, J.A. (1970a) Androgens in systemic plasma of male guinea-pigs during development and after castration in adulthood. Endocrinology 86, 14441447.

Resko, J.A. (1970b) Androgen secretion by the fetal and neonatal rhesus monkey. Endocrinology 87, 680687.

ReSKo, J.A., FedeR, H.H. \& GoY, R.W. (1968) Androgen concentrations in plasma and testis of developing rats. J. Endocr. 40, 485-491.

Rivarola, M.A., Snipes, C.A. \& Migeon, C.J. (1968) Concentration of androgens in systemic plasma of rats, guinea-pigs, salamanders and pigeons. Endocrinology 82, 115-121.

Shapiro, B.H. \& LeatheM, J.H. (1970) Aging and adrenal $\Delta 5$-3 $\beta$-hydroxysteroid dehydrogenase in female rats. Proc. Soc. exp. Biol. Med. 136, 19-20.

SNipes, C.A., Forest, M.G. \& Migeon, C.J. (1969)
Plasma androgen concentrations in several species of old and new world monkeys. Endocrinology 85, 941-945.

Stearns, E.L., MacDonnell, J.A., Kaufman, B.J., Padua, R., Lucman, T.S., Winter, J.S.D. \& FaIMAN, C. (1974) Declining testicular function with age. Am. J. Med. 57, 761-766.

SWerdloff, R.S., WALSh, P.C., JACOBS, H.S. \& Odell, W.D. (1971) Serum LH and FSH during sexual maturation in the male rat: effect of castration and cryptorchidism. Endocrinology 88, 120-128.

Tremblay, R.R., Forest, M.G., Shalf, J., Martel, J.G., Kowarski, A. \& Migeon, C.J. (1972) Studies on the dynamics of plasma androgens and on the origin of dihydrotestosterone in dogs. Endocrinology 91, 556-561.

Vermeulen, A., Rubens, R. \& Verdonck, L. (1972) Testosterone secretion and metabolism in male senescence. J. clin. Endocr. Metab. 34, 730-735.

Wieland, R.G., Chen, J.C., Zorn, E.M. \& Hallberg, M.C. (1971) Correlation of growth, pubertal staging, growth hormone, gonadotrophins and testosterone levels during the pubertal growth spurt in males. J. Pediatrics 79, 999-1002.

Received 22 March 1976 